\title{
MUSEUM DALAM PERSPEKTIF PARIWISATA DAN PENDIDIKAN
}

\author{
OLEH: \\ ILHAM JUNAID \\ DOSEN POLITEKNIK PARIWISATA NEGERI MAKASSAR \\ Email: illank77@yahoo.co.id
}

SOSIALISASI MUSEUM, 20 NOVEMBER 2017

MUSEUM LA GALIGO

DINAS KEBUDAYAAN DAN PARIWISATA

PROVINSI SULAWESI SELATAN

2017 


\section{Pendahuluan}

'Ayo berkunjung ke museum', sebuah tagline atau slogan yang mengajak masyarakat (publik) untuk meluangkan waktu dan berkunjung ke museum di manapun mereka berada. Hasilnya, setiap tahun jumlah pengunjung museum semakin meningkat jika dilihat dari angka statistik. Pengelola museum juga semakin bersemangat untuk merencanakan dan menjalankan berbagai program kerja atau aktifitas yang berhubungan dengan koleksi, memberikan pemahaman kepada masyarakat mengenai arti dan tujuan pengelolaan museum, dll. Masyarakat juga mulai antusias berkunjung ke museum, mengajak anggota masyarakat lainnya khususnya keluarga (misalnya anak-anak) untuk berkunjung ke museum serta keinginan berbagai kalangan atau kelompok masyarakat untuk memanfaatkan museum sebagai tempat untuk belajar, penelitian serta memahami sejarah dan budaya suatu bangsa.

Di Indonesia, perhatian akan eksistensi museum telah menunjukkan hasil yang positif. Di berbagai wilayah di Indonesia, telah dibuka berbagai jenis museum serta kegiatan yang diperuntukkan untuk melibatkan masyarakat berkunjung ke museum. Penulis mendapat kesempatan berkunjung ke museum angkut yang berada di kota Batu, Malang. Faktanya, para pengunjung harus mengikuti antri untuk masuk ke museum tersebut, harus membayar, kemudian membutuhkan waktu yang tidak sedikit untuk melakukan eksplorasi seluruh koleksi atau tata pamer koleksi museum tersebut. Museum angkut setidaknya telah mampu mengubah cara pandang masyarakat bahwa museum bukanlah tempat yang membosankan atau kurang menyenangkan. Rekan penulis (rombongan dari Makassar) yang berkunjung ke museum tersebut telah memahami bahwa museum dapat menjadi daya tarik wisata yang layak untuk dikunjungi bahkan sebagai tempat untuk belajar dalam suasana yang rileks atau santai.

Di balik sisi positif yang disajikan museum untuk publik atau dari kunjungan ke museum, tidak dapat dihindari bahwa masih ada sebagian atau sekelompok masyarakat yang memiliki cara pandang (paradigma) kurang baik tentang museum. Suatu kesan yang menganggap museum tidak lebih dari gudang atau tempat benda-benda kuno untuk tujuan dipamerkan ke masyarakat dan tanpa nilai. Tugas kita bersama sebagai anggota masyarakat adalah memberikan pemahaman kepada mereka mengenai arti, manfaat dan tujuan 
pendirian atau pengelolaan museum. Kenyataannya, tidak sedikit dari masyarakat yang belum pernah berkunjung ke museum. Di kalangan dunia pendidikan misalnya, masih banyak mahasiswa (misalnya mahasiswa pariwisata dan hospitaliti) yang belum pernah berkunjung ke museum. Selain itu, mahasiswa jurusan budaya atau sejarah mungkin masih ada yang belum berkunjung ke museum. Karena itu, perlu ada usaha untuk mendorong mereka untuk meluangkan waktu melihat bukti-bukti sejarah dan budaya bangsa dengan berkunjung ke museum.

Makalah atau karya tulis ini bertujuan untuk a) memberikan pemahaman kepada pembaca mengenai arti penting museum; b) menguraikan museum sebagai daya tarik wisata dan museum sebagai media atau tempat belajar (peran pendidikan museum) serta c) memberikan informasi bagaimana seharusnya masyarakat (termasuk wisatawan) memulai atau melakukan aktifitas berkunjung ke museum. Tulisan ini didasarkan pada pengalaman penulis memanfaatkan museum sebagai daya tarik wisata dan tempat belajar bagi mahasiswa serta berdasarkan pada kajian pustaka atau teoretis museum, kepariwisataan dan pendidikan.

\section{Arti dan Tujuan Pengelolaan Museum}

Pemahaman akan arti dan defenisi museum banyak diadopsi dari institusi atau lembaga internasional yang memberikan perhatian khusus pada pengelolaan museum. The International Council of Museums (ICOM) misalnya, memberikan defenisi museum dengan penekanan pada berbagai aspek yakni museum sebagai institusi yang non-profit atau lembaga yang bekerja dengan tidak mencari keuntungan. Penulis pernah ditanya oleh seseorang mengenai mengapa pengunjung museum harus membayar ketika akan masuk museum. Alasan yang mungkin dapat diterima adalah ketika suatu museum dikelola oleh swasta, maka sumber pendanaan untuk pengelolaan dan pemeliharaan koleksi adalah dari biaya masuk pengunjung (entrance fee). Karena itu, beberapa museum menerapkan pembayaran bagi mereka yang akan menikmati pengalaman berkunjung ke museum. Bagi museum yang dikelola oleh pemerintah, jumlah yang dibayarkan biasanya tidak lebih dari Rp. 5000, jumlah yang tidak terlalu besar bagi pengunjung yang menikmati museum sebagai media belajar dan daya tarik wisata. Dana yang diperoleh dari kunjungan ini 
sebenarnya sebagai pemasukan yang diperuntukkan bagi pembangunan daerah termasuk untuk pengelolaan museum.

Penekanan kedua adalah bahwa museum merupakan lembaga yang memberikan pelayanan (service) kepada masyarakat (publik). Pemberian layanan ini berkaitan dengan pemberian informasi kepada publik khususnya pengunjung mengenai bagaimana kedudukan dan fungsi museum, informasi mengenai koleksi museum serta kegiatan yang dilaksanakan oleh pengelola museum. Pemberian layanan ini tidak terlepas dari peran pengelola (staf) museum baik sebagai pemberi informasi maupun sebagai pihak yang mempersiapkan tata pamer koleksi melalui peran kurator.

Dalam menjalankan tugasnya, pegawai atau staf museum melaksanakan pengoleksian, dokumentasi, konservasi koleksi, memamerkan koleksi dan memberikan informasi mengenai koleksi yang dipamerkan. Langkah-langkah tersebut dijalankan dengan prinsip penelitian (research) yang memungkinkan mereka mengkomunikasikan nilai atau informasi yang terkandung pada koleksi tersebut. Jadi, ketika melakukan kunjungan ke museum, pengunjung seharusnya memanfaatkan informasi yang ada baik melalui pemandu (staf) maupun melalui informasi tertulis yang ada pada tata pameran museum. ICOM sebagai organisasi museum dunia memastikan bahwa museum dimanfaatkan oleh publik sebagai media atau tempat pendidikan serta penikmatan bukti material manusia dan lingkungannya. A museum is a non-profit making, permanent institution in the service of society and its development, and open to the public, which acquires, conserves, researches, communicates and exhibits, for purposes of study, education and enjoyment, material evidence of people and their environment (ICOM, 2004).

Kita (publik) perlu memahami tipe atau klasifikasi museum. Ambrose dan Paine (2006) mengklasifikasikan museum dari berbagai sudut pandang yang mencakup museum dilihat dari jenis atau klasifikasi koleksi, museum dilihat dari siapa yang mengelola atau menjalankan museum tersebut, museum ditinjau dari cakupan atau lokasi museum tersebut, museum ditinjau dari siapa audiens (audience) atau diperuntukkan untuk siapa museum tersebut, serta klasifikasi museum dilihat dari cara koleksi museum dipamerkan atau tata pameran museum. 
Dilihat dari jenis koleksinya, museum dapat diklasifikasikan ke dalam tipe atau jenis museum umum, museum arkeologi, museum seni, museum sejarah, museum etnografi, museum sejarah alam, museum sains, museum geologi, museum industri, dan museum militer. Ketika pengunjung melihat koleksi museum, mereka dapat saja melihat berbagai jenis koleksi yang dipamerkan. Jenis koleksi ini akan bervariasi tergantung dari koleksi yang dipamerkan. Jenis koleksi museum dapat terdiri dari koleksi etnografika (koleksi yang berhubungan dengan benda-benda budaya atau antropologi), koleksi numismatika (koleksi yang berhubungan dengan mata uang), koleksi filologika (koleksi yang berhubungan dengan naskah-naskah), koleksi keramologika (yang berkaitan dengan keramik), koleksi biologika (yang berhubungan dengan disiplin ilmu biologi), koleksi historika (yang berhubungan dengan sejarah), koleksi heraldika (yang berhubungan dengan lambang-lambang).

Ditinjau dari segi pengelolanya, museum dapat dikategorikan sebagai museum pemerintah dan museum swasta. Museum juga dapat dibagi secara spesifik khususnya bagi siapa yang mengelola museum tersebut yakni museum yang dikelola suatu lembaga pendidikan, misalnya universitas, museum mandiri yang dikelola sekelompok orang atau individu (mandiri), serta museum yang dikelola oleh suatu organisasi atau perusahaan. Ditinjau dari segi area pelayanan, museum dapat dikelompokkan ke dalam museum nasional, museum regional (provinsi), museum kota dan museum lokal. Selanjutnya, ditinjau dari segi audiens (audience), museum dibagi ke dalam tiga bagian yakni museum publik atau umum (general public museum), museum pendidikan dan museum spesialist (specialist museum). Museum juga dapat diklasifikasikan ke dalam museum tradisional, ekomuseum atau open air museum, dan museum interaktif.

\section{Museum Dalam Perspektif Pariwisata}

Ketika melakukan perjalanan ke suatu daerah tujuan wisata (destinasi wisata), tidak sedikit pengunjung atau wisatawan mencari lokasi dimana bukti sejarah dan budaya suatu bangsa di destinasi tersebut dapat dilihat. Mereka yang senang akan budaya atau sejarah cenderung meluangkan waktu untuk mencari museum untuk melihat koleksi yang dipamerkan. Wisatawan seperti ini dapat dikategorikan sebagai wisatawan budaya (cultural tourist). 
Berkunjung ke museum merupakan aktifitas pariwisata budaya (cultural tourism), jenis pariwisata dimana wisatawan mengunjungi aset budaya atau halhal yang berkaitan dengan kebudayaan suatu masyarakat di destinasi wisata. Dalam hal kunjungan ke museum, istilah wisatawan dan pengunjung perlu dibedakan. Lambert (2011) membedakan dua istilah tersebut, pertama, wisatawan (tourists) diartikan sebagai "any individual who visit cultural institutions or places such as archaeological and heritage sites, operas, theatres, festivals or architecture and museum while away from home". Sementara itu, visitors diartikan sebagai "any individual who visits museums or galleries whether at home or at a destination". Dari defenisi di atas, dapat dipahami bahwa istilah pengunjung lebih tepat digunakan ketika wisatawan yang datang berkunjung ke museum. Wisatawan yang datang ke destinasi wisata dan berkunjung ke museum serta masyarakat yang berkunjung ke museum dikategorikan sebagai pengunjung (visitor) museum.

Terdapat pula kategori wisatawan yang senang dengan alam atau menikmati keindahan dan segala aktifitas yang berkaitan dengan alam ketika mereka berada di destinasi wisata. Mereka yang mencintai alam ini mungkin saja berpotensi untuk mengunjungi museum selain melakukan eksplorasi alam. Mason (2003) mengelompokkan tiga jenis motivasi wisatawan dalam melakukan perjalanan yakni motivasi untuk bersenang-senang (pleasure), motivasi yang sifatnya profesional (misalnya mengikuti pertemuan, bisnis, dll), serta motivasi lainnya (misalnya, untuk studi, alasan kesehatan, dll.) Motivasi pleasure memiliki banyak tujuan misalnya, melihat budaya masyarakat dan alam di suatu destinasi. Pada dasarnya, wisatawan yang datang ke suatu destinasi dapat menjadi pengunjung museum atau sangat berpotensi untuk mengunjungi museum. Karena itu, pariwisata dan museum adalah dua hal yang tak dapat dipisahkan satu sama lain.

Museum merupakan daya tarik wisata baik yang berada di daerah perkotaan maupun yang saat ini berada di kabupaten di Sulawesi Selatan. Suatu daerah dapat memiliki potensi daya tarik wisata alam, budaya dan buatan. Museum dapat dikategorikan sebagai daya tarik wisata buatan (built environment attraction). Museum dibangun untuk kebutuhan pelestarian koleksi serta penikmatan manusia atas eksistensi suatu benda-benda peninggalan manusia. 
Ketika melakukan kunjungan ke destinasi wisata, wisatawan akan diperhadapkan pada suasana lingkungan yang variatif. Dalam kondisi seperti ini, manusia (atau wisatawan) akan melakukan adaptasi dengan lingkungan. Karena itu, dalam konteks pariwisata, terdapat dua pendekatan yang dapat terjadi ketika wisatawan mengamati suatu lingkungan yang ada (misalnya museum) yakni pendekatan atau cara dimana ia berusaha untuk semakin mendekati (approaching) sesuatu. Kedua, cara atau tingkatan dimana ia berusaha untuk menghindari sesuatu (Bonn, dkk, 2007). Dalam hal ini, sikap yang berkaitan dengan mendekati (approach behaviors) diartikan sebagai sikap positif terhadap sesuatu dengan keinginan untuk lebih lama tinggal, melakukan eksplorasi, mengeluarkan uang yang mereka miliki melalui pembelian produk atau layanan, serta melakukan pencarian terkait yang berkaitan dengan lingkungan.

Pendekatan atau sikap menghindari (avoidance) dapat diartikan sebagai sikap seseorang untuk tidak tinggal lebih lama, tidak ada keinginan untuk melakukan eksplorasi lebih jauh, serta tidak ada keinginan untuk memahami lebih dalam kondisi lingkungan dimana ia berada. Dalam hal seseorang berada di suatu museum, maka kedua pendekatan ini dapat terjadi, apakah ia berkeinginan untuk melakukan eksplorasi lebih jauh atau sebaliknya, merasakan kecukupan informasi dan tidak ingin melakukan eksplorasi lebih jauh dari apa yang sedang ia kunjungi atau saksikan. Kita mengharapkan, seseorang yang berkunjung mengalami sikap atau tingkah laku positif yakni keinginan untuk tinggal lebih lama dan mencari pengalaman yang lebih jauh ketika berkunjung ke suatu museum.

Pengalaman yang diperoleh pengunjung museum dapat terwujud ketika mereka mengalami atau merasakan secara langsung lingkungan fisik di sekitar mereka. Dalam konteks museum, mereka akan melihat tata pamer koleksi (display) yang ada di museum, atau daya tarik yang ada di museum. Kondisi fisik museum (baik interior dan eksterior) yang mengesankan adalah modal awal sebuah museum untuk dikembangkan. Karena itu, dibutuhkan hal-hal untuk diperhatikan dalam mengembangkan museum sebagai daya tarik wisata. Woollard (2004) menyarankan 2 (dua) pendekatan yang perlu diperhatikan untuk mengoptimalkan museum sebagai daya tarik wisata yakni pelayanan pengunjung (visitor services) dan akses bagi pengunjung (access for visitors). 
Pelayanan pengunjung dapat diartikan sebagai pengelolaan museum dengan memberikan kesempatan kepada pengunjung untuk mendapatkan pengalaman kunjungan yang informatif dan menyenangkan. Salah satu indikator dari pelayanan ini adalah kemampuan pengelola museum membantu pengunjung menikmati koleksi yang dipamerkan serta kegiatan atau event yang dilaksanakan. Pelayanan pengunjung ini juga berkaitan dengan bagaimana pengunjung dapat menggunakan berbagai fasilitas yang dimiliki museum. Kegiatan yang dilakukan oleh museum, misalnya seminar atau pemanduan mengenai informasi koleksi, penelitian, serta pelaksanaan pameran koleksi (misalnya temporary exhibition) harus memastikan kemampuan pengunjung memperoleh kesempatan ikut dalam kegiatan tersebut. Jika memungkinkan, pengunjung dapat bertemu dengan para staf untuk memperoleh penjelasan mengenai museum. Dengan kata lain, dalam pelaksanaannya, museum terbuka kepada publik, baik kepada pengunjung untuk tujuan rekreatif maupun untuk tujuan edukatif.

Sistematika atau langkah-langkah visitor melakukan kunjungan ke museum dapat dibagi ke dalam 2 (dua) bagian yakni pengunjung dengan dipandu oleh pemandu (guide) dan pengunjung tanpa pemandu. Staf museum (misalnya museum La Galigo) menyambut pengunjung dan diiringi dengan administrasi untuk masuk museum. Idealnya, pengunjung dipandu oleh guide yang menemani mulai dari masuk museum hingga mereka keluar dari gedung museum. Pemanduan oleh tenaga pemandu ini dapat dilihat dari kondisi pengunjung, misalnya tamu/pengunjung rombongan dimana mereka sebaiknya didampingi oleh pemandu (guide) yang memiliki pengetahuan mengenai koleksi. Terdapat pula pengunjung yang tidak memerlukan pemandu karena mungkin alasan ingin melihat secara langsung informasi yang ada pada vitrin koleksi. Pada proses pemanduan ini, informasi yang diberikan serta layanan yang diberikan oleh staf museum akan sangat memengaruhi kepuasan pengunjung. Karena itu, pemandu yang ditugaskan seharusnya memiliki kompetensi pemanduan.

Keterbatasan staf atau pemandu di suatu museum menjadi salah satu alasan ketidakmampuan museum memberikan layanan pemanduan bagi seluruh pengunjung. Hal ini dikategorikan sebagai pengunjung tanpa pemandu. Untuk memberikan pelayanan maksimal kepada kelompok pengunjung ini, maka 
informasi koleksi museum sangat berperan dalam memberikan informasi kepada pengunjung. Pengunjung selayaknya dituntun dengan tata pamer museum khususnya yang berkaitan dengan alur pengunjung. Alur perjalanan pengunjung dengan tata pamer koleksi yang menarik memungkinkan mereka untuk tinggal lebih lama di dalam museum mempelajari dan menikmati koleksi yang ada. Dalam hal ini, aktifitas koleksi yang menarik dan variatif dengan pemanfaatan audio visual dan teknologi akan menjadi pendorong bagi pengunjung memperoleh kesan positif tentang museum. Kedua pendekatan tersebut di atas (dengan atau tanpa pemandu) akan berdampak pada 2 (dua) kemungkinan kesan bagi pengunjung yakni positif atau biasa saja. Tujuan yang diharapkan adalah kesan pengunjung yang positif dengan keinginan untuk berkunjung kembali serta merekomendasikan ke teman atau kolega untuk berkunjung ke museum.

\section{Museum Dalam Perspektif Pendidikan}

Museum dalam perspektif pendidikan dapat dipahami sebagai pemberian layanan pendidikan (education) (Hooper-Greenhill, 1994; Plourde, 1994) oleh museum ke para pengunjung atau proses pemanfaatan museum sebagai media pembelajaran oleh pengunjung atau masyarakat. Pendidikan dikategorikan sebagai pendidikan yang sifatnya formal dengan pemanfaatan sekolah sebagai sumber atau tempat belajar dan pembelajaran yang sifatnya informal, salah satunya di museum. Sebaliknya, museum dapat menjadi alternatif bagi para pengajar di berbagai tingkat pendidikan formal untuk membawa siswa atau pebelajar belajar di museum atau memanfaatkan museum untuk mendukung kegiatan pembelajaran. Dalam perkembangannya, sudah terdapat beberapa sekolah yang merencanakan dan melakukan kunjungan resmi ke museum sebagai bagian dari kurikulum pendidikan formal di sekolah. Selain itu, museum pada umumnya telah menyediakan ruang khusus untuk pembelajaran yang sifatnya formal (seperti kelas) untuk keperluan pembelajaran di museum. Jadi, perkembangan pengetahuan dan kreatifitas pengajar sangat mendukung pemanfaatan museum sebagai sumber belajar.

Peran pendidikan museum salah satunya dapat dilihat dari bagaimana institusi pendidikan (sekolah dan universitas) memanfaatkan museum melalui aktifitas belajar mengajar (Hooper-Greenhill, 1994). Pendekatan pertama adalah 
jika siswa tingkat Sekolah Dasar (SD) merencanakan berkunjung ke museum. Guru sebagai penanggung jawab kelas dapat (sebaiknya) melakukan komunikasi dengan pihak museum mengenai rencana kunjungan ke museum. Untuk kota Makassar, terdapat 3 (tiga) museum yang dapat menjadi alternatif kunjungan yakni Museum La Galigo, Museum Kota Makassar dan Museum Pattingalloang di kawasan Benteng Somba Opu. Sebagai alternatif, pengelola museum dapat secara aktif melakukan komunikasi, kemitraan atau kerjasama dengan pihak sekolah untuk mengundang sekolah (siswa) berkunjung ke museum. Dalam hal ini, dibutuhkan kreatifitas dari pihak guru (sekolah) dan staf museum untuk menjadikan museum sebagai media atau sumber belajar.

Langkah kedua adalah identifikasi target pembelajaran dan strategi atau teknis kunjungan ke museum. Target pembelajaran ini bervariasi tergantung dari capaian mata pelajaran dan pokok bahasan yang menjadi harapan pendidik/pengajar. Guru sekolah dan pihak museum dapat melakukan komunikasi untuk mendiskusikan target belajar dan aktifitas yang dapat dijalankan ketika murid berkunjung ke museum. Beberapa target atau informasi yang diharapkan diketahui oleh siswa, misalnya apa itu museum, tujuan museum, nama tokoh dan peranannya, sejarah, nama benda budaya dan kegunaannya, kegiatan menggambar, dan berbagai aktifitas kreatif lainnya.

Ketika melakukan kunjungan, guru atau pemandu memberikan penjelasan kepada para murid, kemudian para murid berjalan mengikuti alur sesuai tata pameran koleksi museum. Guru pendamping atau staf museum sebaiknya tidak membiarkan murid berjalan sendiri di museum tanpa ada pemandu. Terdapat kecenderungan murid berjalan dan berlari di museum tanpa memerhatikan informasi yang seharusnya mereka dapatkan selama berkunjung. Karena itu, pembagian kelompok murid ketika berkunjung ke museum menjadi alternatif bagi para pengajar ataupun pemandu museum untuk memaksimalkan proses belajar.

Pada tingkat SMP atau SMU, rencana pembelajaran di museum dimulai dari pemikiran kreatif dari para pengajar (guru). Guru mata pelajaran di sekolah dapat menyesuaikan materi pembahasan dengan museum yang akan dikunjungi maupun dengan jenis koleksi yang dipamerkan. Pada bagian awal dijelaskan bahwa koleksi museum terbagi atas berbagai jenis koleksi. Dari jenis koleksi ini banyak mata pelajaran yang dapat masuk ke dalam kategori pembelajaran 
museum. Untuk tingkatan SMP dan SMU, identifikasi pembelajaran dapat berupa pelajaran bahasa, biologi, sejarah dan budaya, geografi, teknologi, dll. Jika guru memahami museum dan mampu berfikir kreatif, maka banyak mata pelajaran yang dapat bersentuhan dengan koleksi museum. Selanjutnya, rencana kunjungan ke museum dapat dikomunikasikan dengan pengelola museum khususnya kegiatan yang akan dilakukan oleh museum.

Pada tingkatan SMP dan SMU, kegiatan kunjungan ke museum dapat dilakukan dengan tugas berkelompok dan mandiri. Tugas guru adalah memberikan instruksi mengenai tugas-tugas yang harus diselesaikan. Selanjutnya, pengelola museum (pemandu) memberikan informasi sesuai kebutuhan pengunjung serta aktifitas yang dapat dilakukan oleh para siswa. Para pendamping harus memastikan bahwa aktifitas yang dilakukan oleh para siswa sesuai dengan target dan harapan sekolah selain melakukan proses belajar secara rileks.

Pengunjung pada tingkat mahasiswa (perguruan tinggi) lebih banyak diberikan secara mandiri meskipun tugas secara berkelompok sangat dianjurkan. Penulis beberapa kali membawa mahasiswa jurusan pariwisata berkunjung ke museum dan memastikan bahwa aktifitas yang mereka jalankan adalah memahami dan mengelola museum sebagai daya tarik wisata dan memanfaatkan museum sebagai tempat atau sumber informasi. Beberapa mata kuliah sangat relevan untuk proses pembelajaran pendukung selain pertemuan secara formal di dalam kelas. Pada umumnya, cakupan pembelajaran pengunjung pada taraf perguruan tinggi adalah penelitian. Mahasiswa sangat dianjurkan melakukan penelitian di museum dengan topik yang variatif dengan latar belakang keilmuan yang variatif pula. Tingkah laku pengunjung, tata letak koleksi, teknologi dan informasi, sejarah dan budaya adalah beberapa topik penelitian yang dapat dilakukan di museum. Beberapa museum memiliki fasilitas penunjang pembelajaran. Karena itu, penulis menyarankan pentingnya komunikasi yang intens antara para pengajar dan pengelola museum. 


\section{Kesimpulan}

Sebagai anggota masyarakat yang berada di suatu wilayah geografis, sudah selayaknya kita memahami potensi kepariwisataan yang terdapat di daerah kita termasuk eksistensi museum sebagai daya tarik wisata. Museum dapat menjadi pilihan masyarakat untuk belajar dan bersantai (rekreatif), tentunya dengan rekomendasi positif dari mereka yang pernah berkunjung ke museum. Semakin banyak masyarakat (termasuk wisatawan) yang mengunjungi museum, maka semakin terbuka peluang bagi masyarakat untuk memahami sejarah dan budayanya. Eksistensi museum tidak dapat berperan dengan baik untuk masyarakat jika aspek pendidikan tidak menjadi perhatian pengelola. Sebaliknya, museum juga harus mampu mendorong masyarakat untuk berkunjung ke museum tidak hanya dalam konteks pendidikan, tetapi sebagai tempat rekreatif yang mampu memberikan suasana yang menyenangkan, tidak membosankan, aktifitas variatif dan museum sebagai daya tarik wisata budaya.

Beragam target pembelajaran baik oleh pelajar SD, SMP, SMU hingga perguruan tinggi dapat diimplementasikan di museum. Pembelajaran sejarah dan budaya di museum adalah sebagian kecil dari kreatifitas pengajaran yang dapat dijalankan oleh pengajar. Untuk mencapai tujuan tersebut, dibutuhkan kreatifitas guru atau pengajar untuk memanfaatkan museum sebagai peluang atau tempat belajar informal bagi peserta didik mereka. Kerjasama antara sekolah dan pengelola atau staf museum untuk mengimplementasikan target pembelajaran ini perlu segera diterapkan. Bagi mereka yang belum pernah berkunjung ke museum sebaiknya meluangkan waktu untuk datang dan melihat tata pamer koleksi yang ada di museum. Hal ini untuk memastikan bahwa pengunjung (khususnya pengajar) mampu berfikir kreatif menerapkan strategi pembelajaran dan pengajaran di museum, selain proses belajar mengajar secara formal di sekolah. Selamat mencoba. Terima kasih.

\section{Saran}

Tulisan ini memandang perlunya setiap anggota masyarakat untuk memanfaatkan museum sebagai tempat rekreatif atau daya tarik wisata serta pusat belajar berbagai jenis pelajaran atau mata kuliah. Penulis menyarankan kepada 2 (dua) kelompok masyarakat yakni pengelola museum dan masyarakat secara umum agar tujuan rekreatif dan pendidikan museum dapat tercapai. 
Kepada pengelola museum, penulis menyarankan pentingnya memerhatikan atau menjawab pertanyaan-pertanyaan karena menyangkut pengelolaan museum yang profesional dan menarik masyarakat datang ke museum.

- Mengapa publik atau masyarakat (masyarakat potensial) berkunjung ke museum?

- Apa yang memotivasi mereka untuk mengunjungi museum?

- Siapa yang akan mengunjungi museum?

- Apa karakteristik pengunjung museum?

- Kapan mereka akan datang ke museum?

- Apakah mereka (pengunjung) akan berkunjung kembali dan seberapa sering mereka berkunjung?

- Berapa lama (waktu) yang dihabiskan(mereka akan tinggal di museum) ketika mereka melakukan kunjungan?

- Siapa atau apakah yang menjadi pesaing museum?

- Apa kekuatan dan kelemahan museum yang saya kelola?

- Apa yang dapat dipelajari oleh suatu museum dari kekuatan dan kelemahan tersebut?

- Bagaimana bentuk pasar (market) dari museum?

- Apakah pasar (market) museum saya semakin besar atau semakin kecil setiap tahunnya?

Pertanyaan di atas dapat menuntun pengelola museum dalam menjalankan tugas pengelolaan museum. Pertanyaan tersebut dapat dijadikan sebagai bahan rujukan untuk memastikan bahwa museum yang saat ini dikelola mampu memenuhi harapan wisatawan dan masyarakat secara umum dan pengunjung secara khusus.

Bagi peserta (masyarakat), penulis memberikan saran berupa pertanyaan yang dapat dijadikan bahan evaluasi sebagai berikut:

- Apakah saya (anda) sudah pernah berkunjung ke museum?

- Seberapa sering saya (anda) berkunjung ke museum?

- Apakah saya (anda) telah merekomendasikan kepada kolega atau kelompok masyarakat lainnya untuk berkujung ke museum? 
- Kreatifitas pembelajaran dan pengajaran apa yang dapat saya (anda) terapkan di museum?

- Apakah saya (anda) telah melakukan kerjasama dengan pengelola museum untuk membawa siswa, pebelajar atau rekan datang ke museum?

- Selain untuk tujuan pendidikan, apakah saya memanfaatkan museum sebagai tujuan lainnya (rekreatif).

Penulis menyarankan kepada masyarakat untuk memberikan jawaban ya pada setiap pertanyaan berikut. Selanjutnya, dibutuhkan usaha yang maksimal dari kita semua untuk mendukung program pemerintah (khususnya pemerintah daerah) untuk mewujudkan museum sebagai daya tarik wisata dan media pendidikan. Jawaban ya untuk pertanyaan tersebut sebaiknya segera diwujudkan agar kita memahami arti dan fungsi pengelolaan museum. Selamat mencoba.

\section{Ayo berkunjung ke museum.}

\section{Daftar Pustaka}

Ambrose, T., \& Paine, C. (2006). Museum basics (2nd ed.). New York: Routledge.

Bonn, M. A., Joseph-Mathews, S. M., Dai, M., Hayes, S., \& Cave, J. (2007). Heritage/cultural attraction atmospherics: creating the right environment for the heritage/cultural visitor. Journal of Travel Research, 45(3), 345-354. doi: $10.1177 / 0047287506295947$

Hooper-Greenhill, Eilean (1994). Who goes to museum. Dalam Hooper-Greenhill, Eilean (Editor). The educational role of the museum, hal. 47-60. London: Routledge.

Hooper-Greenhill, Eilean. (1994). Museum education. Dalam Hooper-Greenhill, Eilean (Editor). The educational role of the museum, hal. 229-257. London: Routledge.

ICOM (2004). Running a museum: A practical handbook. ICOM: Paris.

Mason, P. (2003). Tourism impacts, planning and management. Burlington: Butterworth-Heinemann. 
Plourde, Lynn. (1994). Teaching with collections. Dalam Hooper-Greenhill, Eilean (Editor). The educational role of the museum, hal. 275-278. London: Routledge.

Stylianou-Lambert, T. (2011). Gazing from home: cultural tourism and art museums. Annals of Tourism Research, 38(2), 403-421.

Woollard (2004). Caring for the visitor. Running a museum: A practical handbook. ICOM: Paris. 